\title{
THE FINANCIAL SECTOR OF THE STATE - THE STRUCTURE \\ OF THE BANKING SYSTEM WITH A BANKING SECTOR IN CENTRAL AND EASTERN EUROPEAN COUNTRIES
}

\author{
Ljiljana Stošić Mihajlović \\ High School of Applied Studies in Vranje, Republic of Serbia \\ mihajlovicp@ptt.rs \\ Ljiljana Jović \\ High Business School of Vocational Studies, Novi Sad, Republic of Serbia \\ joviclj@hotmail.rs
}

\section{Original Scientific Paper doi:10.5937/jouproman5-15302}

\begin{abstract}
The financial sector of each country in the world has its own specificities that depend on many factors. In this paper we will talk about the structure of the financial system in our country from the aspect of the banking sector. Banks are specialized institutions that have a special role in the development of the country's economic system, as their basic function is to supply the economy with the necessary amount of loans and money. Banking business is a special economic activity. It is determined by the type and content of banking operations. In general terms, banking transactions are divided into two groups: active and passive. The Bank is established as a joint-stock company, which is regulated by the laws on banks and international regulatory frameworks.
\end{abstract}

Key words: financial system, banks, banking operations

\section{INTRODUCTION}

In general, the most important activities that banks deal with as economic institutions within the financial system are:

- payment transactions;

- receiving cash deposits;

- Foreign exchange and exchange transactions;

- issuing guarantees;

- placement and borrowing;

- issuance, custody, management, purchase and sale of securities;

Within the banking system, depending on the business activities, it is possible that all banks in the domestic financial market are divided into several types. Also, depending on the specificity of each country, it is possible to create a parallel of the banking sectors in certain countries. Within this paper, there will be a special review of the banking sector in the countries of Central and Eastern Europe.

\section{GENERAL CHARACTERISTICS OF BANKS}

"The economic system can be defined as a set of methods and standards adopted by the company to enable it to decide and organize the distribution of limited economic resources to satisfy unlimited human needs. Alternatively, the 'economic system' refers to the organizational arrangements and the process through which society makes its product and process decisions. Creating and changing their economic system, every society chooses between alternative objectives and alternative decisions."( Stošić-Mihajlović, Lj. [2015]. Conditionality economic policy and economic system. Journal of Process Management. New Technologies, 3(1), 7683.)

The Central Bank represents an independent, unique and emission institution of the monetary system. In many countries, the Central Bank is otherwise called the National Bank. 
It deals with monetary policy, financial discipline and performs other tasks that are defined by legal rules. The central bank can realize all its functions through monetary instruments, and the most important instruments are: mandatory reserve, discount rate, minimum liquidity reserve, participation in foreign exchange transactions, purchase and sale of securities. Of course, the central function of the central bank is the emission function of money. This function is reduced to the emission of paper and coins. Central banks can issue primary money by approving loans to commercial banks. In this way, the central banks of all countries maintain the necessary amount of money in circulation, thus regulating the level of the interest rate on the financial markets.

Commercial (deposit) banks are banks, which are mostly represented in the banking systems of each state. They are characterized by a diversified network, a large number of branches, as well as a large number of clients from all over the country. In most countries, commercial banks are the most important financial intermediaries. Deposit banks approve loans to their clients, taking into account the liquidity and security of investing funds. In the banking sector, deposit banks are the most liquid banks, which transfer liquidity to other market participants. Modern banking has led to the fact that deposit banks have taken the leading position in terms of profitability. The total surplus of commercial cash or as they are often called, commercial banks - invest in securities that have high yields in terms of interest, dividends and capital gains. Depository banks are very important players in the money market, as well as in the capital market. In the money market, short-term financial instruments such as short-term securities, such as deposit certificates, commercial and treasury bills, bank acquisitions, repro-instruments are traded. While the capital market is traded exclusively with long-term financial instruments (eg securities with a maturity of more than one year).

Universal banks are banks that deal with all banking business operations (except for the issue of paper and coins, which is the exclusive right of the Central Bank). It can be said that the deposit function is the basic function of these banks. Universal banks are not specialized banks, they can provide services that are related to the nonbanking sector. The activities of these banks include the provision of financial services, such as insurance services, guarantees for the issue of securities, transactions with securities, loan approval and acceptance of deposits. The characteristic of this type of banks is that they can establish holding companies because they have share capital in other companies. In Serbia, most banks are of a universal type, their control is difficult because there is a close connection between them and the business sector.

Commercial banks are banking organizations that represent the product of a market type of business, they are established with their own financial resources. Financial reports have a major role in this type of banks, especially their balance sheet and profit and loss accounts must be studied. In the balance sheet, assets are assets, while liabilities include sources of funds used by the bank in its operations. The income statement shows the realized financial result of the bank. If it happens that the bank has a loss, the bank's reserves will serve to cover it. Business banks are usually incorporated into companies that have large annual turnover, whereby commercial banks need to support the operation of these companies. Usually banks lend growth and development, based on long-term deposits. 
Specialized deals with certain banking activities, such as import and export business, investment activities, securities transactions, foreign exchange transactions and various other specialized banking activities. While branch banks deal with banking business for the needs of production groups of companies, individual businesses, business branches. Usually such banks are called "investment" or "commercial" banks.

Savings houses and savings and loan organizations are usually established by local governments, whereby they are public-law financial organizations. The role of savings banks is:

- to mobilize free cash by broadcasting bonds,

- placement of funds through loans, bonds,

- transformation of money into capital,

- trade with bonds

Savings - credit unions perform their activities only within the framework of their founders or their members. The emphasis is on collecting deposits and granting loans to members of the bank, ie savings and credit cooperatives.

\section{BANKING ASSETS (ASSETS) OF BANKING SECTOR}

In most countries, a set of mandatory financial statements, which comprise the annual conclusion or annual accounts of banks, include: balance sheet, income statement, cash flow statement, statement of changes in equity, as well as notes to the financial statements, considered as integral part of the report. While the balance sheet and the income statement are the two most well-known, traditionally used financial statements, the cash flow statement is a new type of document. The common characteristic of all three reports is that they are compiled on the basis of a single basis, i.e. the same and equally measured basic transactions and business events.
The balance sheet provides financial information on assets, liabilities and share capital of the bank, showing its financial position on a specific day, balance sheet date (December 31 of current year). The assets of the balance sheet contain the assets of the bank, ie it shows the use of funds of the bank, such as money and reserves on the account with a central bank or other banks, placements in securities and placements in loans. Liabilities represent the carrying amount of nonresidents (deposits, funds based on issued securities and loans taken), and the share capital of proprietary rights to assets of the bank, shown in the assets. The analysis of the bank's balance sheet is based on the analysis of assets and liabilities, i.e. assets, liabilities and capital, which is expressed as follows:

$$
\begin{gathered}
\text { Asset }=\text { Liabilities } \\
\text { Assets = Liabilities }+ \text { Capital }
\end{gathered}
$$

Banking balances represent a significant information base for the rational analysis and construction of various indicators for measuring banking performance. Identification and monitoring of balance sheet positions enables the assessment of the liquidity and solvency situation, the amount of potential risks, as well as the degree of intermediation of banks on the market. In this context, the cash rate, the liquidity rate and the capital rate represent only some of the more indicators that draw data for their construction from the balance sheet, which serve for the purpose of assessing the performance position of the bank, as well as for the comparison of banking positions within the banking system. The analysis and comparison of the balance sheet positions of banks with previous periods makes it possible to assess the performance of banks, the quality of the bank's management, the manual transformation and the sectoral structure of assets. 
Banks are financial institutions that offer a wide range of different services. Bankers point out that the assets and liabilities of the bank should be viewed as an integrated unit. In doing so, account must be taken of the way in which the overall portfolio of the bank contributes to profitability, as a primary goal. In order to manage the assets and liabilities of the bank in an adequate manner it means defining the bank's strategies, controlling the banking processes, as well as the liquidity of the bank's assets. The main objective of managing balance positions is to create the corresponding level of net interest income. Only if there is an optimal combination of the level of assets and financial risks of the bank, it is possible to realize the main goals in the business.

The assets in the business comprise loans that the bank can offer and the required reserve, which banks can place on the market of the loan capital. Assets often include money in circulation. Certain theorists believe that the assets contain securities. When analyzing the operations of banks, the assets can consist of loans that are placed on the market of the loan capital and the required reserve. Such loans come from funds such as savings and savings on the one hand, and on the other hand, sight deposits. When it comes to mandatory reserves, the rates of obligatory reserves are determined by the central banks, since the obligatory reserve is certainly one of the most important monetary policy instruments.

The structure of assets according to the principle of rising liquidity is as follows:

- immobilization,

- supplies,

- receivables,

- cash Money.

Liquidity structure according to the principle of rising liquidity:

- own sources (capital),

- long-term liabilities and provisions,
- short-term liabilities.

The balance sheet of the bank is balanced if the values of assets and liabilities are manually and currency adjusted. Solvency is expressed through share capital and reserves, thus defending the stability of the business system.

Bank asset management involves placing funds in those alternatives that will enable the acquisition of high profits, while the risk will be reduced to the minimum. When it comes to managing the bank's assets, it is meant to manage cash, securities, credit placements and other forms. It is very important that banks maintain a certain level of liquid reserves so that client orders can be executed without any delay. The management in banks should structure the deposits and adjust the maturity between the placements and the sources of funds in the bank. With each increase in risk, profits increase, and vice versa. Management always has a dilemma of whether to focus on a business that has a higher risk, and therefore a higher profit, or at a lower risk, but less and profits. The main problem is that interest of shareholders and management are opposed. Namely, there is always a "conflict" between liquidity and profitability. The bank's shareholders are putting pressure on the management of the bank to realize as much profit as possible on the basis of placements, with an increased volume of interest-bearing placements, which directly threatens the liquidity principle in the bank. On the other hand, management wants to increase the liquidity of the bank, at a price that profitability is at a lower level. Deponents are also for maintenance and monitoring of liquidity. If there would be favoritism of the shareholders' interests, this would lead to the withdrawal of demand deposits, which further leads to greater insolvency of the bank and the outflow of stable depositors. 
There are three theoretical and practical approaches to managing the assets and liabilities of a bank:

- Grouping assets - applies when a bank has a large amount of funds. The essence is that the bank can place its available assets in any form of assets, without taking into account the origin of assets. Placement is done in securities, fixed assets, primary reserves, secondary reserves and loans.

- Asset allocation (conversion of assets) the general liquidity of the bank's assets is placed in the forefront, in order to put liquid clients' demands in the second plan (concerning term deposits, savings deposits, demand deposits and equity of the bank). This model ignores the principle of profitability of the bank. It would be necessary to link the amounts of liquid needs with the source from which the funds are encouraged, where each source of funds is analyzed individually and linked to certain placements. If the sources of funds originate from the demand deposits, the management of the bank will allocate their majority part in the primary liquidity reserve, and the minority part in the secondary reserve, and the least part in the loans placement.

- Linear programming - The application of the linear programming model implies that the management of the bank is well aware of the banking business in the bank itself. The model should recognize decision problems and select the best alternatives for the profitability and liquidity of the bank.

When it comes to managing liabilities, the liabilities of the banks' balance sheets contain the deposit, non-deposit sources and capital of the bank. Depending on the size, the structure of the passive depends. In larger banks, the relationship between deposit and non-deposit sources is better compared to smaller banks. Deposits take the dominant position in the bank's sources of funds. The theoretical approach to the management of the liability relies on the fact that the bank is an active participant in structuring its sources of funds. From the aspect of the functional approach to managing the bank's liabilities, the Bank's management adjusts the source of its funds in accordance with the demand for loans, minimizing the risks and costs in the bank. A functional approach to managing a passive has an advantage over the theoretical approach. Two models for managing the liability are possible, with the first starting from the grouping of assets, while the other model implies increasing the profitability of placements.

Under conditions of uncertainty of cash flows, cost of financing and costeffectiveness of investments, the bank must determine the optimal relationship between risks, collection and liquidity. ALM concept (Asset and Liability Management) represents simultaneous management of assets and liabilities of a bank. The ALM concept is a model that involves analyzing and predicting liquidity in order to prevent it in a timely manner, or to take action to overcome timely. It relates to short-term weather.

From this aspect, the banking sector of Central and Eastern European countries is very specific in all its characteristics. In 2014, the diversification of the portfolio of banks was tested. Some of the basic features are the growth of assets that are still strong in the countries of Central and Eastern Europe than in the European Union. Banking operations in Central Europe continue to record progress, refocusing business strategies across countries instead of significant mergers and acquisitions activities. Speaking of efficiency in the banking business of this region, it is possible to double the value of return on capital. 
Strengthening of this region was temporarily halted in 2008, when the first serious signs of a financial crisis, spreading from the west to the east, showed up. Today, markets have stabilized and economic forecasts are optimistic, although a lot of new banking regulations have been adopted in the Euro zone, there is plenty of room for concern and uncertainty. It can be considered that 2014 is a turning point for the European banking sector, as the strategies for diversification of the assets of banks operating in Central and Eastern Europe will be tested. Analyzes show that most countries in the region today are stronger and more stable than they were six years ago.

\section{BACKGROUND OF THE BANKING SECTOR IN CENTRAL AND EASTERN EUROPE COUNTRIES}

Over the past several years, the financial and banking system of Central and Eastern Europe has been rapidly evolving. First of all, modern regulations are introduced and new financial institutions are established, which have had an impact on maintaining the macroeconomic stability of the entire region. The financial market in central and eastern Europe, before the onset of the recession, was unstable, underdeveloped, extremely risky compared to the Western European economies. The banking sector represents the most important segment of the financial system of Central and Eastern European countries and as such is the bearer of the financial structure.

The whole of the chapter will be applied, on the one hand, by the unique methodology of grouping Central and Eastern European countries. Observed lands will be divided into three groups. The first group consists of countries, which are already largely members of the European Union, such as Slovenia, Slovakia, the Czech Republic, Poland and Hungary. Therefore, this group consists of the most developed countries in the region of Central and Eastern Europe. The second group consists of countries such as Bulgaria, Romania and Croatia, which joined the EU a few years later. These are the countries that were last received in the EU, especially Croatia that joined in 2013. The countries of the other group managed to meet the major demands that were set before them by the EU. The third group consists of countries that are in the process of transition and are still making significant efforts to join the EU and become equal members. Among other things, there are Serbia, Bosnia and Herzegovina, Montenegro, the former Yugoslav Republic of Macedonia and Albania. Accordingly, third-country countries have the lowest levels of economic and economic development. The countries of this part of the Balkans face a slowdown in economic activity, which is a result of a lack of production. The price of banking products is considerably higher than in the rest of Europe. Interest rates on loans are at a high level, especially when it comes to the so-called. Cash loans in domestic currencies. Banks are constrained by the view that the region of the Western Balkans is very risky, especially when it comes to political instability. High unemployment rates exceeding $25 \%$, the problem is the public debt that countries have towards their creditors.

\subsection{Current situation and development of the banking sector}

The banking market in Central and Eastern Europe is relatively weak and insufficiently developed compared to the European Union (EU). In early 2005, a large number of foreign banks interested in entering this market appeared in Serbia and countries in the region. The leading banking groups in Western Europe have experienced an expansion in Central and Eastern Europe over the past few years, which can confirm the size of banking assets and capital, which is owned by foreign banks. 
This claim is supported by the fact that at least $70 \%$ of the banking market in South and Eastern Europe is currently controlled by foreign banking groups. However, when the global economic crisis began and the recession saw a decline in the financial activity of Western European banks in the Central and Eastern European (CEE) region. This trend continues even today, because the number of attractive banks that could be taken was reduced. Total economic growth is slowed down and in the financial sector there is a deficit of liquid assets.

Between the banking sector on the one hand and the economic and social development of the country, on the other hand, there is a close and mutual connection. The development of the banking sector is influenced by numerous economic and demographic factors, among which the most important is the amount of gross domestic product (GDP), where annual growth in gross domestic product is expressed in percentage terms. Aggregates are important macroeconomic indicators that measure the results of the country's economy activities and are used for macroeconomic analysis. Aggregates of national accounts are vital for realistic planning and successful implementation of economic policy. Gross domestic product is an indicator of economic activity on the whole country level.

Between the banking sector on the one hand and the economic and social development of the country, on the other hand, there is a close and mutual connection. The development of the banking sector is influenced by numerous economic and demographic factors, among which the most important is the amount of gross domestic product (GDP), where annual growth in gross domestic product is expressed in percentage terms. Aggregates are important macroeconomic indicators that measure the results of the country's economy activities and are used for macroeconomic analysis. Aggregates of national accounts are vital for realistic planning and successful implementation of economic policy. Gross domestic product is an indicator of economic activity on the whole country level.

Table 1. GDP level for the analyzed group of countries in the period 2008-2015 (EUR billion) 2008

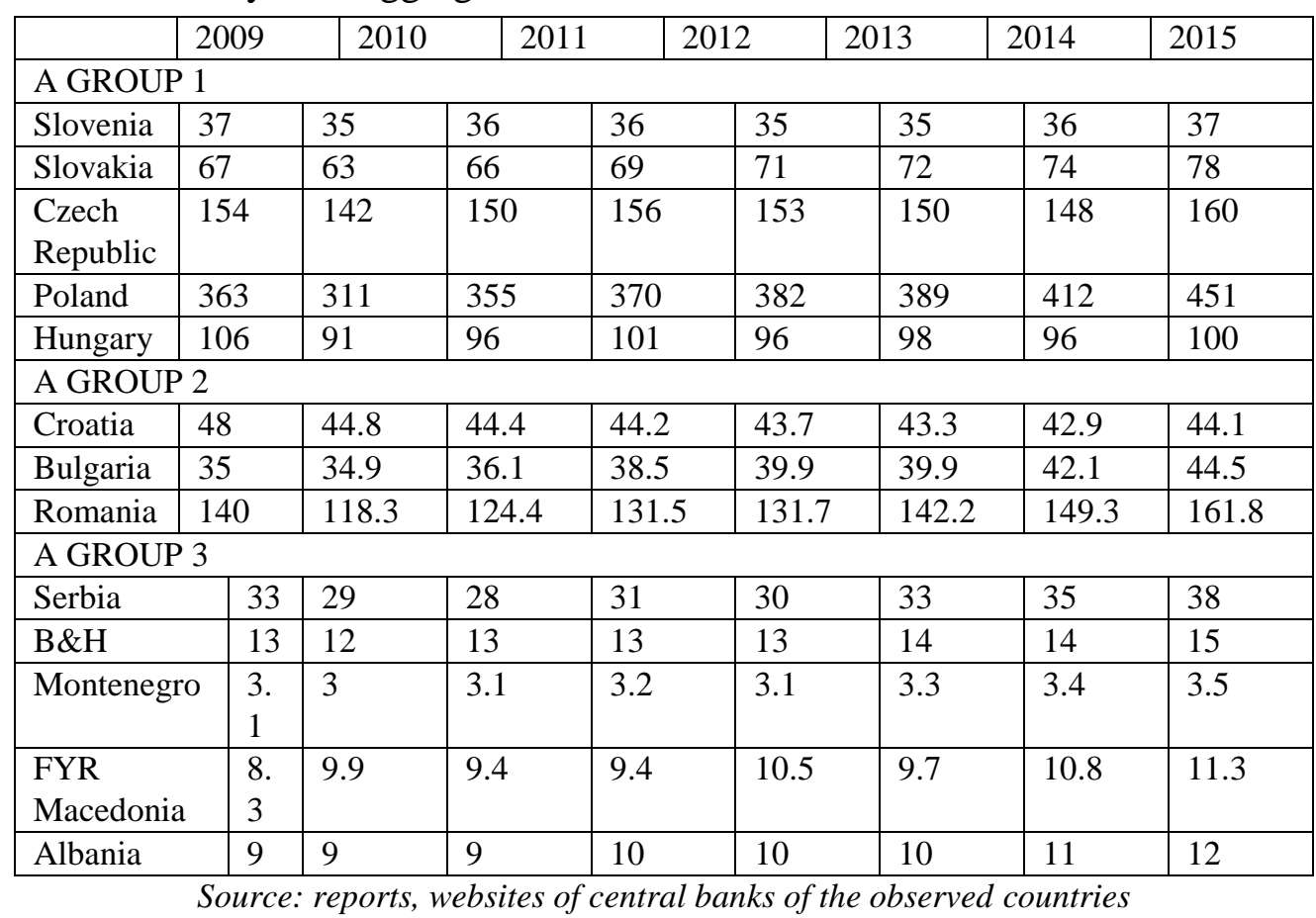


(JPMNT) Journal of Process Management - New Technologies, International Vol. 5, No 4, 2017.

Tabela 2. GDP per capita for the CIE region in the period 2008-2015 (in EUR) 2008

\begin{tabular}{|l|l|l|l|l|l|l|l|l|}
\hline Slovenia & 18,372 & 17,355 & 17,317 & 17,616 & 17,153 & 17,087 & 17,273 & 17,855 \\
\hline Slovakia & 12,393 & $\begin{array}{l}11,63 \\
8\end{array}$ & 12,137 & 12,777 & 13,151 & 13,301 & 13,669 & 14,312 \\
\hline $\begin{array}{l}\text { Czech } \\
\text { Republic }\end{array}$ & 14,785 & $\begin{array}{l}13,60 \\
6\end{array}$ & 14,274 & 14,835 & 14,576 & 14,216 & 14,074 & 15,193 \\
\hline Poland & 9,517 & 8,152 & 9,206 & 9,612 & 9,902 & 10,100 & 10,701 & 11,729 \\
\hline Hungary & 10,503 & 9,119 & 9,619 & 10,145 & 9,674 & 9,876 & 9,755 & 10,104 \\
\hline Croatia & 10,722 & 10,11 & 10,045 & 10,305 & 10,221 & 10,172 & 10,098 & 10,413 \\
\hline Bulgaria & 4,658 & 4,618 & 4,804 & 5,255 & 5,483 & 5,520 & 5,858 & 6,228 \\
\hline Romania & 6,499 & 5,509 & 5,804 & 6,142 & 6,565 & 7,106 & 7,470 & 8,106 \\
\hline \multicolumn{7}{|c|}{ GROUP 3 } \\
\hline Serbia & 4,445 & 3,955 & 3,841 & 4,317 & 4,083 & 4,557 & 4,858 & 5,230 \\
\hline B\&H & 3,290 & 3,222 & 3,298 & 3,418 & 3,415 & 3,561 & 3,661 & 3,891 \\
\hline Montenegro & 5,010 & 4,843 & 4,999 & 5,156 & 4,991 & 5,311 & 5,470 & 5,631 \\
\hline $\begin{array}{l}\text { BJR } \\
\text { Makedonia }\end{array}$ & 3,341 & 3,520 & 3,505 & 3,620 & 3,701 & 3,682 & 3,777 & 3,917 \\
\hline Albanija & 2,785 & 2,743 & 2,928 & 3,445 & 3,563 & 3,686 & 4,003 & 4,221 \\
\hline EU & 25,900 & 24,300 & 25,300 & 26,000 & 26,500 & 26,600 & 27,300 & - \\
\hline
\end{tabular}

GDP per capita in all countries is high on the eve of the global economic crisis, in order to see oscillations in the crisis years from 2009 to 2012. Recovery years start from 2013, which can be seen from the enclosed. The country with the largest amount of GDP and the GDP per capita in the region is Slovenia, where the range is from 17,087 to 18,372 euros per capita. The Czech Republic and Slovakia have lower levels, where in 2011 the Czech Republic registers 14,835 euros, while Slovakia at the end of 2014 records 13,669 euros per capita. Countries such as Poland, Hungary and Croatia have slightly lower levels of GDP per capita than the previous countries. The average value for these three countries is around 10,000 euros. The lowest levels of this indicator are recorded in B\&H, the Former Yugoslav Republic of Macedonia and Albania, where the values range from 2,785 to 3,915 euros.

The development of banking represents the basis for the development of the national economy, since it performs the function of mobilization of free funds in the form of savings. Funds collected can be used both in the process of crediting and solving economic problems, as well as in encouraging the progress of the national economy. Thus, sustainable economic growth stimulates the development of the banking sector, which contributes to the successful economic advancement of the national economy. In the upcoming period, the expansionary monetary policy of the European Central Bank will be implemented and increasingly will work on the harmonization of international regulatory frameworks in the markets.

For European banking, the previous year was a year of extensive debt reduction. The consequences of the spread of this trend in the Central and Eastern European (CEE) region were again limited, regardless of the overall positive picture, some of the foreign banks in Central and Eastern Europe continued to implement certain strategies. Research shows that Western European banks have fundamentally changed their portfolios for the past five years, focusing on more profitable and less risky markets. This trend will also be transferred to the banks of Central and Eastern Europe, which have their headquarters in the countries of Western Europe, through various diversification strategies. 
The main feature of the banking sector in the CEE region is that there are still differences between countries. In Central and Eastern European countries, a slower acceleration of credit growth can be expected, mainly due to crediting to the corporate sector. External commitments are increasingly being replaced by financing in the domestic market, reducing previous exposure. Return on assets of the banking sector of Central and Eastern Europe should be as in 2014, with the amount of $1.0 \%$. Analyzing trends across the country, there are good signs that credit growth will be achieved in the region of central and eastern Europe. Gradual acceleration of growth should be represented throughout the region, due to lending to the corporate sector. Taking into account that profit margins are under Chart 1. Total gross credit growth per annum for the region of central, eastern and south-eastern Europe in the period 2010-2014 (\%)

Source: (UniCredit, 2015: 5)

Central and Eastern Europe

Central and Eastern and South Eastern Europe

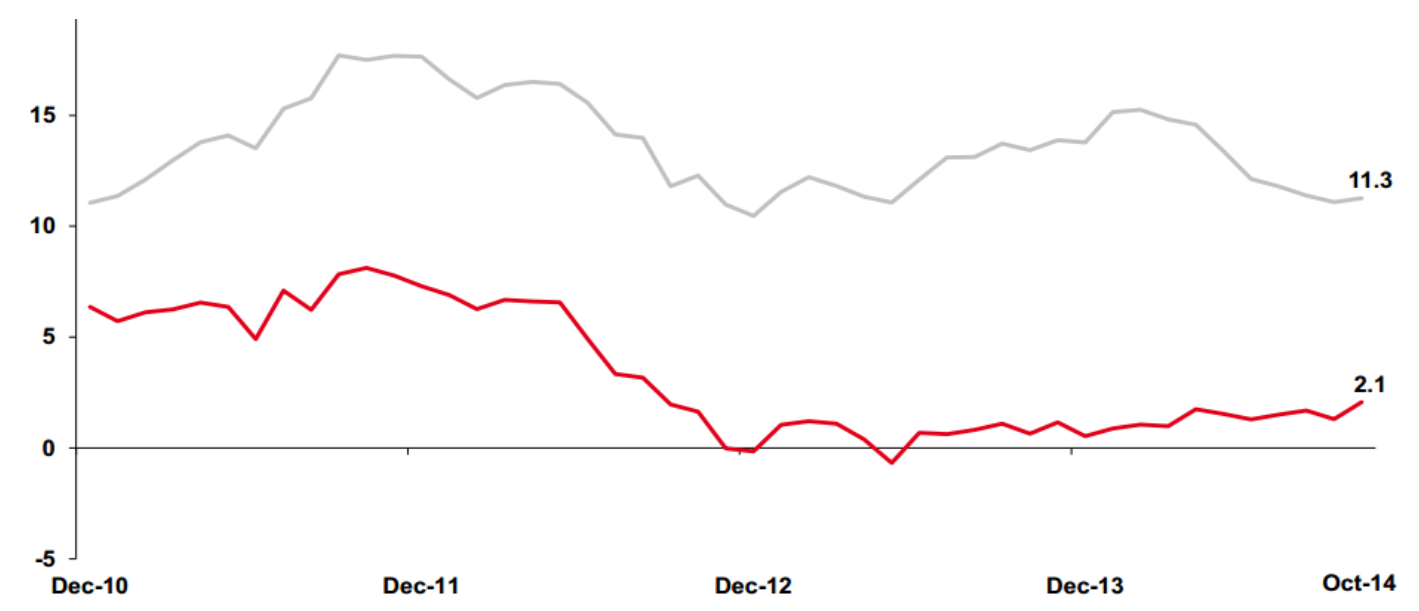

In the following period, solid lending growth in Central and Eastern Europe can be expected, due to loans intended for the corporate sector. Czech Republic and Poland will continue to lead credit recovery in Central Europe, so that Croatia and Slovenia could return to positive pressure, it can be expected that noninterest income will be an important driver of profitability.

Lending represents the most important business activity for each bank and greatly affects the development of the economy. Oscillations between individual countries exist, because interest rates on loans are different for countries from our first, second and third groups. The countries of the first group have the most favorable interest rates, followed by the countries of the second and third countries of the third group, which have the highest interest rates not only in the region of central and eastern Europe, but also in the wider. The following graph will show the total gross loan growth in percentages per annum for the region observed. 
Chart 2. Gross credit growth annually for the region of central, eastern and south-eastern Europe in the period 2010-2015 in\% (total loans, household loans, corporate loans)

Source: (UniCredit, 2015:10)

Central and Eastern Europe

Central and Eastern and South Eastern Europe

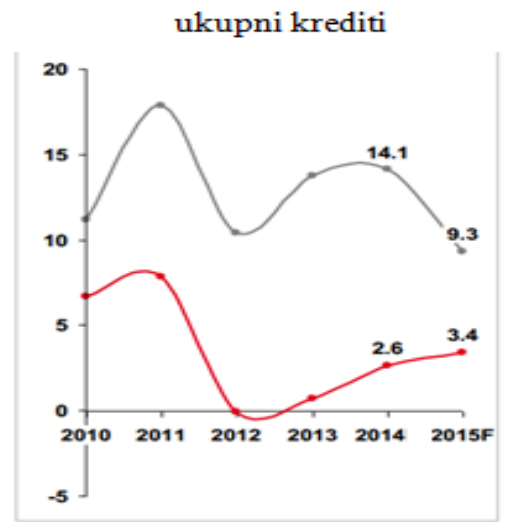

In the analysis of the most important parameters in banking operations, the level of problem loans (non-performing loans) should not be omitted. Non-performing loans and their

Graphicon 1. Level of problem loans in relation to total loans for the region of central, eastern and south-eastern Europe in the period 2009-2015 (\%)

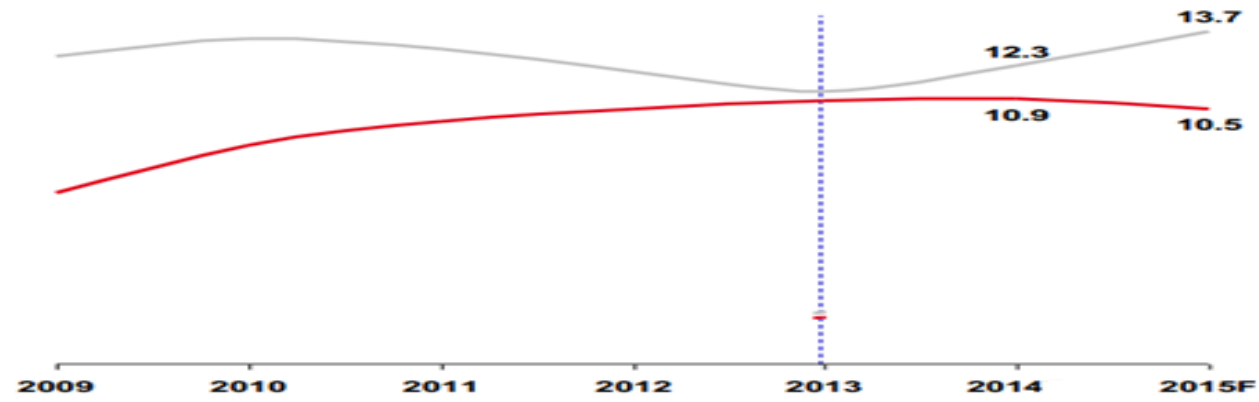

coverage will surely continue to be the most important challenge. In general, all countries have high NPL values. korporativni krediti

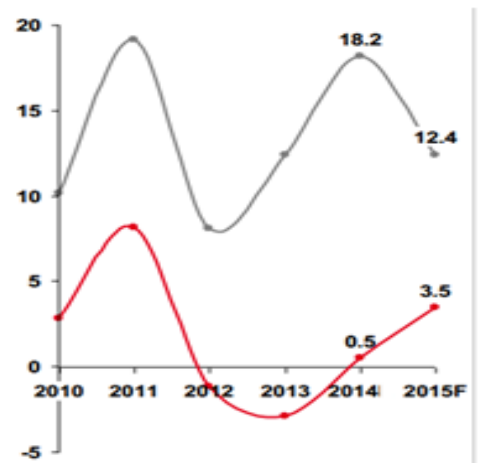

Source: (UniCredit, 2015:10)

Central and Eastern Europe

Central and Eastern and South Eastern Europe

Since the global crisis had an impact on economies around the world during 2008, there is a significant deterioration in the quality of banking assets and the increase in the share of problem loans from year to year. Such developments are becoming apparent in the countries of Southeast Europe where the level of problem loans has continued to grow in the coming years in order to reach an average level of almost $17 \%$ at the end of 2012 (in 2008, the average NPL ratio was close to $6 \%$ ).

During the crisis period (2008-2012), the countries of central and eastern Europe had a NPL growth rate higher than the 
Debt growth occurred because interest rates were rising, altered by the level of risk and the price of banks' sources in these countries;

- Clients used short-term loans to finance long-term investments. This kind of financing has made it impossible for banks to invest their assets. Corporate governance in companies in this region is largely late for developed countries.

Banks have recently changed credit policies, business is shifting from market share and quantity to profitability and portfolio quality. Regardless of the change in business policy, it is noted that other indicators again have an impact on the growth of NPLs. In particular, the real economy is stagnating throughout the region.

\subsection{Efficiency of the banking sector}

When analyzing the results of operations, the bank is viewed as a cash enterprise and hence there is a specific measurement of business efficiency. One of the best performance indicators is the return on equity. The market price is also one of the indicators when selling the bank. It is considered not to be an adequate indicator, because it rarely comes to sales. The most important indicators of return for banks can be: interest margin, return on equity, return on assets, operating profit, commission interest without interest, as well as income on ordinary shares.

Yields and risks are highly interconnected, since lower risk also ensures lower returns, so banks must take into account the basic principles and principles of banking operations. The Banking Act imposes the establishment of a special unit that will deal with internal control. Such an organizational unit should control the compliance of banks' operations with laws, international regulatory standards, and the principles of banking operations. Audits of annual reports are mandatory and must be made available to the public.

The analysis of business performance implies consideration of the following factors:

- Measurement method of yield

- which are key indicators of yield

- optimal relationship between risk and yield

- business compliance and internal control

- internal and external audit.

The method of yield measurement implies possible approaches in the analysis and measurement itself. The analysis of bank operations is based on the same indicators as with all other companies. The Bank is regarded as a financial enterprise with the basic indicator return on equity (ROE). The best indicator of business success would be the market price achieved on the market. However, there are problems related to the market price of banks, regarding the underdevelopment of the markets in the countries in transition. Expert judgment is very important in analyzing the profitability coefficient.

The most important and most important indicators of business efficiency are in fact yield indicators (profitability), which are represented in all countries. International banking practice uses the following indicators:

- ROE (Return on Equity) - is the most important indicator for shareholders, as it shows how much shareholders have returns relative to invested funds in shares. By comparison with other banks, this indicator draws attention to the extent to which an attractive new issue of stocks will be attractive. ROE shows the operational efficiency of the bank. It is obtained as follows:

$\mathrm{ROE}=(\mathrm{ROA} \times \mathrm{T}$ Total assets $) /$ Total share capital 
By further disaggregation, it is shown that the level of profits that shareholders are highly sensitive to the bank's source structure on the property side. The relationship between ROA and ROE expresses the relation of risk and yield. If there is a decline in business efficiency from the point of view of generating revenue on funds placed on the market, the bank can apply a higher risk of borrowing.

- ROA (Return on Assets) represents the return on assets, indicating how effectively managed the bank's assets. It is best to use the average amount of assets over the year to avoid seasonal oscillations that may occur. From the aspect of profitability, new models of financing are introduced, whereby the most important indicator of profitability, return on assets.-

Interest margin represents the difference in income (interest rate) and expense (deposit interest rate).

Operating profit shows the performance of the management, to enable faster growth of revenues from expenditures. Operating profit is obtained in the following way: total operating income - expenses / total assets. EPS (Earnings per share), earnings per ordinary share, are a very important indicator for stock analysts.

- A non-interest-based commission margin - there is a tendency to increase the share of these revenues, for now they are negative values. It can be obtained as a difference between non-interest income and non-interest expenses, and when fees and other expenses are deducted from commissions and revenues. Margins are still under pressure, banks should expand their capabilities in order to increase revenue generation capacity.

It is always important to measure the relationship between yield and risk for the management of the bank. This analysis requires a change in the bank's performance indicators, which involves an analysis of individual jobs. All countries deal with their banking laws in a comprehensive way to control the compliance of business, internal controls, internal and external audits. The Executive Committee is responsible for carrying out internal control. Banks should form a Bank Monitoring Committee, as well as the Organizational Unit for Compliance of the Bank's Operations and the Internal Audit Organizational Unit. The organization, competencies and manner of operation of the Organizational unit for compliance of the bank's operations are defined by the Decision on the manner and conditions for the identification and monitoring of the compliance risk. The risk of business compliance includes in particular: the risk of financial loss, the reputation risk and the risk of sanctions of the regulatory body.

The harmonization of bank operations with regulations is the work of the Bank's Board of Auditors, the Audit Committee and the Internal Audit Department. Where internal audit is an independent and objective opinion of the Board of Directors. Employees are obliged to provide them with all relevant information and documents. They are obliged to inform the Executive and Steering Committee, especially when it comes to weaknesses.

An external audit is performed by an audit firm. The auditor should not depend on the audit of one bank (over half of annual revenues), it can carry out the audit maximum three times in a row. It is mandatory to publish a summary in the daily newspapers.

The efficiency and profitability of the banking sector can be best demonstrated by the following scheme, where the most important parameters are presented, such as the efficiency and profitability of the banking sector over a certain period of time. The model is presented on the basis of the analysis of the banking sector of Serbia, conducted by Veroljub Dugalić. The model can serve as a basis for analysis of other banking sectors. 
Figure 2-3. Efficiency and viability of the banking sector in Serbia in the period 2008-2012

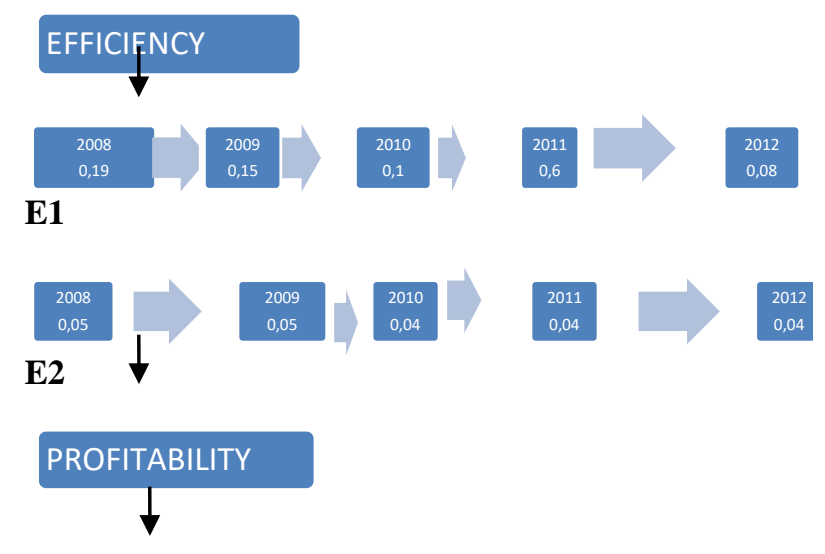

Source: (Dugalić, 2013)

\begin{tabular}{|l|l|l|l|l|l|}
\hline & 2008. & 2009 & 2010 & 2011 & 2012 \\
\hline $\begin{array}{l}\text { Rate of return on total } \\
\text { assets (pre-tax) }\end{array}$ & $1,13 \%$ & $1,97 \%$ & $1,0 \%$ & $\begin{array}{l}0,04 \\
\%\end{array}$ & $0,4 \%$ \\
\hline $\begin{array}{l}\text { Return on equity } \\
\text { (before tax) }\end{array}$ & $5,3 \%$ & $8,3 \%$ & $5,1 \%$ & $0,2 \%$ & $1,9 \%$ \\
\hline
\end{tabular}

By observing the banking system of Central and Eastern Europe, it can be concluded that the structure itself is very diverse. Deposit institutions dominate in each country, where commercial and universal banks are particularly distinguished. The following table will show the structure of the banking system of each country for the observed period. The initial analysis will be done in relation to the market share of domestic state and foreign banks. Some of the criteria for foreign banking groups to enter new markets are:

- lower level of gross domestic product per capita;

- higher percentage of educated population;

- developed credit and financial markets;

- low inflation rate;

- projections of high economic growth and high yields.
Given the classification, an analysis of the observed groups will be carried out. In group 1, it can be noted that the market share of foreign banks on average for all years is about $74 \%$, while the share of domestic state banks is only about $26 \%$. It should be emphasized that these are countries that are already largely members of the European monetary system. On the other hand, in Group 2, the market share of domestic state banks is on average $18 \%$, while foreign banks have a share of $82 \%$. What points to the fact that in these countries the overall support to the economic system is given by foreign banks. More precisely, banks that are already a lot of leaders in the markets of Western Europe. In the third group, the situation is similar, with countries that are not yet EU member states. These are countries that are in the process of transition and reform of the economic system.

The fact is that in developed financial systems, such as certain group 1 countries, the state can independently form its own banks and provide support to the entire financial system. In conditions of poor economic development, this is an aggravating circumstance because the construction of a stable and robust banking system is an extremely difficult task for each country. What is characteristic of all three groups, more precisely for all the countries observed, is that there are a large number of banks. The average value is 31 banks per country. This indicator is very important because it points to the fact that in the region of central and eastern Europe there is a problem of too many banks, socalled overbanking. Tendencies in the future will be aimed at reducing the number of banks through mercury and acquisitions, the procedure for bank tightening will be spelled out. 
(JPMNT) Journal of Process Management - New Technologies, International

Vol. 5, No 4, 2017.

Table 3. Structure of the banking sector for the analyzed countries of Central and Eastern Europe (2008-2014)

\begin{tabular}{|c|c|c|c|c|c|c|c|}
\hline $\begin{array}{l}\text { Market share of } \\
\text { foreign banks } \\
\text { (\% of total } \\
\text { assets) }\end{array}$ & 38.2 & 29 & 28 & 29 & 31 & 31 & I \\
\hline \multicolumn{8}{|l|}{ Poland } \\
\hline $\begin{array}{l}\text { Number of } \\
\text { banks }\end{array}$ & 70 & 67 & 70 & 66 & 69 & 69 & 64 \\
\hline $\begin{array}{l}\text { Market share of } \\
\text { state banks (\% } \\
\text { of total assets) }\end{array}$ & 17.3 & 21 & 22 & 22 & 21 & 21 & 18 \\
\hline $\begin{array}{l}\text { Market share of } \\
\text { foreign banks } \\
\text { (\% of total } \\
\text { assets) }\end{array}$ & 67 & 63 & 66 & 66 & 63 & 62 & 60 \\
\hline \multicolumn{8}{|l|}{ Hungary } \\
\hline $\begin{array}{l}\text { Number of } \\
\text { banks }\end{array}$ & 38 & 35 & 35 & 35 & 35 & 35 & 39 \\
\hline $\begin{array}{l}\text { Market share of } \\
\text { state banks (\% } \\
\text { of total assets) }\end{array}$ & 3.9 & 4.4 & 4.6 & 5.3 & 5.1 & 5.8 & 12.6 \\
\hline $\begin{array}{l}\text { Market share of } \\
\text { foreign banks } \\
\text { (\% of total } \\
\text { assets) }\end{array}$ & 91.1 & 91 & 90 & 89 & 89 & 88 & 83 \\
\hline \multicolumn{8}{|c|}{ GROUP 2} \\
\hline \multicolumn{8}{|l|}{ Croatia } \\
\hline $\begin{array}{l}\text { Number of } \\
\text { banks }\end{array}$ & 33 & 34 & 33 & 32 & 31 & 30 & 28 \\
\hline $\begin{array}{l}\text { Market share of } \\
\text { state banks (\% } \\
\text { of total assets) }\end{array}$ & 4.4 & 4.2 & 4.3 & 4.5 & 4.8 & 5.3 & 5.1 \\
\hline $\begin{array}{l}\text { Market share of } \\
\text { foreign banks } \\
\text { (\% of total } \\
\text { assets) }\end{array}$ & 90.6 & 91 & 90 & 91 & 90 & 90 & 88 \\
\hline \multicolumn{8}{|l|}{ Bulgaria } \\
\hline $\begin{array}{l}\text { Number of } \\
\text { banks }\end{array}$ & 30 & 30 & 30 & 31 & 31 & 30 & 28 \\
\hline $\begin{array}{l}\text { Market share of } \\
\text { state banks (\% } \\
\text { of total assets) }\end{array}$ & 2.1 & 2.4 & 3.2 & 3.7 & 3.3 & 3.4 & 3.7 \\
\hline $\begin{array}{l}\text { Market share of } \\
\text { foreign banks } \\
\text { (\% of total } \\
\text { assets) }\end{array}$ & 83.9 & 84 & 81 & 76 & 74 & 70 & 76 \\
\hline \multicolumn{8}{|l|}{ Romania } \\
\hline $\begin{array}{l}\text { Number of } \\
\text { banks }\end{array}$ & 42 & 41 & 41 & 40 & 39 & 39 & 39 \\
\hline $\begin{array}{l}\text { Market share of } \\
\text { state banks (\% } \\
\text { of total assets) }\end{array}$ & 5.2 & 7.3 & 7.4 & 8.2 & 8.4 & 8.5 & 8.8 \\
\hline $\begin{array}{l}\text { Market share of } \\
\text { foreign banks } \\
\text { (\% of total } \\
\text { assets) }\end{array}$ & 88.2 & 85 & 85 & 83 & 90 & 90 & 90 \\
\hline
\end{tabular}




\begin{tabular}{|c|c|c|c|c|c|c|c|}
\hline \multicolumn{8}{|c|}{ GROUP 3} \\
\hline \multicolumn{8}{|l|}{ Serbia } \\
\hline $\begin{array}{l}\text { Number of } \\
\text { banks }\end{array}$ & 34 & 34 & 33 & 33 & 32 & 30 & 28 \\
\hline $\begin{array}{l}\text { Market share of } \\
\text { state banks (\% } \\
\text { of total assets) }\end{array}$ & 17.5 & 18.2 & 20.3 & 19.7 & 19.0 & 18.5 & 3.7 \\
\hline $\begin{array}{l}\text { Market share of } \\
\text { foreign banks } \\
\text { (\% of total } \\
\text { assets) }\end{array}$ & 75.3 & 74 & 73 & 73 & 69 & 75 & 76 \\
\hline \multicolumn{8}{|l|}{ B\&H } \\
\hline $\begin{array}{l}\text { Number of } \\
\text { banks }\end{array}$ & 30 & 30 & 29 & 29 & 28 & 27 & 26 \\
\hline $\begin{array}{l}\text { Market share of } \\
\text { state banks (\% } \\
\text { of total assets) }\end{array}$ & 0.9 & 0.9 & 0.8 & 0.9 & 1.0 & 1.0 & / \\
\hline $\begin{array}{l}\text { Market share of } \\
\text { foreign banks } \\
\text { (\% of total } \\
\text { assets) }\end{array}$ & 95 & 95 & 93 & 92 & 92 & 90 & 1 \\
\hline \multicolumn{8}{|l|}{ Montenegro } \\
\hline $\begin{array}{l}\text { Number of } \\
\text { banks }\end{array}$ & 14 & 14 & 14 & 14 & 14 & 14 & 14 \\
\hline $\begin{array}{l}\text { Market share of } \\
\text { state banks (\% } \\
\text { of total assets) }\end{array}$ & / & I & I & I & I & I & I \\
\hline $\begin{array}{l}\text { Market share of } \\
\text { foreign banks } \\
\text { (\% of total } \\
\text { assets) }\end{array}$ & I & 1 & l & I & I & I & I \\
\hline \multicolumn{8}{|l|}{ Albania } \\
\hline $\begin{array}{l}\text { Number of } \\
\text { banks }\end{array}$ & 16 & 16 & 16 & 16 & 16 & 16 & 16 \\
\hline $\begin{array}{l}\text { Market share of } \\
\text { state banks (\% } \\
\text { of total assets) }\end{array}$ & 1 & I & 1 & I & 1 & 1 & I \\
\hline $\begin{array}{l}\text { Market share of } \\
\text { foreign banks } \\
\text { (\% of total } \\
\text { assets) }\end{array}$ & 94 & 94 & 94 & 94 & 94 & 94 & 87 \\
\hline \multicolumn{8}{|l|}{$\mathbf{E U}$} \\
\hline $\begin{array}{l}\text { Number credit } \\
\text { institutions }\end{array}$ & 8558 & 8392 & 8240 & 8093 & 7891 & 7726 & I \\
\hline
\end{tabular}

Source: reports from central banks, commercial banks and international institutions

\subsection{Market share and importance of leading banking groups}

The banking system owners are certainly banking groups that have significant shares in the Central and Eastern European market. These banks are represented almost in each of the mentioned countries. Some of the most famous are SberBank, VTB, UniCredit, Raiffeisen Bank, Erste,
Societe Generale, KBC, Intesa, ING Bank, OTP Bank, Commerzbank, Citibank, Santander, Alpha Bank, Hypo Alpe Adria Bank, Swedbank, NBG Bank, BNP Paribas and EFG Eurobank. Going deeper into the analysis, we analyzed the five largest banks in each observed country. This will indicate the market share expressed in percent for the first quarter of 2014. 
(JPMNT) Journal of Process Management - New Technologies, International Vol. 5, No 4, 2017.

Table 4. Percentage market share of the top 5 banks in the CEE region in the first quarter of 2014

\begin{tabular}{|c|c|c|c|c|c|}
\hline Poland & $\begin{array}{ll}\text { PKO } & \text { Bank } \\
\text { Polski } & \end{array}$ & $\begin{array}{l}\text { Bank Pekao } \\
\text { (UniCredit) }\end{array}$ & $\begin{array}{l}\text { BZ WBK } \\
\text { (Santander } \\
\text { Bank) }\end{array}$ & $\begin{array}{lr}\text { BRE } & \text { Bank } \\
\text { (Comerz } & - \\
\text { bank) } & \end{array}$ & ING Bank \\
\hline \multicolumn{2}{|r|}{14.3} & 10.7 & 7.5 & 7.4 & 6.2 \\
\hline Hungary & OTP & Erste & $\mathrm{K} \& \mathrm{H}(\mathrm{KBC})$ & MKB & CIB (Intesa) \\
\hline \multicolumn{2}{|r|}{21.3} & 8.7 & 7.9 & 7.7 & 7.3 \\
\hline $\begin{array}{l}\text { Czech } \\
\text { Republic }\end{array}$ & Erste & $\begin{array}{l}\text { Societe } \\
\text { General }\end{array}$ & UniCredit & $\mathrm{KBC}$ & $\begin{array}{l}\text { Raiffeissen } \\
\text { Bank }\end{array}$ \\
\hline \multicolumn{2}{|r|}{17.2} & 15.9 & 10.9 & 8.0 & 5.6 \\
\hline Slovakia & Erste & Intesa & $\begin{array}{l}\text { Raiffeissen } \\
\text { Bank }\end{array}$ & $\mathrm{KBC}$ & UniCredit \\
\hline \multicolumn{2}{|r|}{20.7} & 19.0 & 15.7 & 9.3 & 6.9 \\
\hline Slovenia & $\begin{array}{l}\text { Nova } \\
\text { Ljubljanska } \\
\text { banka }\end{array}$ & $\begin{array}{l}\text { Nova kreditna } \\
\text { banka Maribor }\end{array}$ & SID & Abanka Vipa & UniCredit \\
\hline \multicolumn{2}{|r|}{ I } & / & I & I & I \\
\hline Croatia & UniCredit & Intesa & Erste & $\begin{array}{l}\text { Raiffeissen } \\
\text { Bank }\end{array}$ & $\begin{array}{l}\text { Hypo Alpe } \\
\text { Adria Bank }\end{array}$ \\
\hline \multicolumn{2}{|r|}{26.9} & 16.5 & 15.1 & 8.3 & 7.6 \\
\hline Romania & Erste & $\begin{array}{l}\text { Societe } \\
\text { Generale }\end{array}$ & $\begin{array}{l}\text { Banca } \\
\text { Transilvania }\end{array}$ & UniCredit & CEC Bank \\
\hline \multicolumn{2}{|r|}{17.5} & 13.0 & 8.9 & 7.6 & 7.4 \\
\hline Bulgaria & UniCredit & DSK Bank & $\begin{array}{l}\text { First } \\
\text { Investment } \\
\text { Bank }\end{array}$ & $\begin{array}{l}\text { Corporate } \\
\text { Commercial } \\
\text { Bank }\end{array}$ & $\begin{array}{l}\text { United } \\
\text { Bulgarian } \\
\text { Bank }\end{array}$ \\
\hline \multicolumn{2}{|r|}{14.8} & 10.4 & 8.7 & 7.9 & 7.8 \\
\hline \multirow[t]{2}{*}{ Serbia } & Banca Intesa & $\begin{array}{l}\text { Komercijalna } \\
\text { Banka }\end{array}$ & UniCredit & $\begin{array}{l}\text { Societe } \\
\text { Generale }\end{array}$ & $\begin{array}{l}\text { Raiffeissen } \\
\text { Bank }\end{array}$ \\
\hline & 14.7 & 12.2 & 8.7 & 7.3 & 7.0 \\
\hline \multirow[t]{2}{*}{ B\&H } & UniCredit & $\begin{array}{l}\text { Raiffeissen } \\
\text { Bank }\end{array}$ & $\begin{array}{l}\text { Hypo Alpe } \\
\text { Adria Group }\end{array}$ & NLB Group & Intesa \\
\hline & 20.8 & 17.5 & 12.6 & 9.0 & 6.3 \\
\hline Albania & $\begin{array}{l}\text { Raiffeissen } \\
\text { Bank }\end{array}$ & $\begin{array}{l}\text { National } \\
\text { Commercial } \\
\text { Bank }\end{array}$ & Intesa & Credins Bank & Pireaus Bank \\
\hline \multicolumn{2}{|r|}{26.2} & 21.1 & 10.6 & 8.4 & 7.1 \\
\hline Montenegro & Erste & $\begin{array}{l}\text { Societe } \\
\text { Generale }\end{array}$ & $\begin{array}{l}\text { NLB } \\
\text { Montenegro }\end{array}$ & $\begin{array}{l}\text { Crnogorska } \\
\text { komercijalna }\end{array}$ & $\begin{array}{l}\text { Hipotekarna } \\
\text { Banka }\end{array}$ \\
\hline \multicolumn{2}{|r|}{25.16} & 24.30 & 23.02 & 12.8 & 10.23 \\
\hline
\end{tabular}

Taking into account the diversity of the observed countries, it can be noted however that certain foreign groups managed to build their leadership positions, especially UniCredit, Erste and Raiffeisen Bank. Each of these banks has adapted its business conditions to the market and economic conditions of the country in which it operates, applying unique business strategies in each country.

\section{CONCLUSION}

The business of modern enterprises, as well as the life of a modern man, are inextricably linked to banks and banking operations. From the very beginning of the business idea and from its efforts to realize it, the company is sent to the bank, in several segments: in the performance of payment transactions or as the most common source of financing the creation and development of the company. 
Individuals as individuals are also referred to the bank when they try to meet some of the needs across the limits of their monthly budget when they buy apartments, furniture, equipment or cars. (Stošić Mihajlović, Lj., 2015)

How important is the importance of banking to the best illustrate positions in the domestic public about banking before and after the start of the global economic crisis. Prior to the crisis, the public was dissatisfied with the enormously rapid development of domestic banking, and the best illustration of such an approach was the belief that "banks are nothing like mushrooms after the rain," or that "banks open at every corner". More importantly, more important questions concern the large number of newly created jobs in banks for young people, educated people, and the fact that in this period, due to the great expansion of the credit activities of banks, rapid economic development was enabled.

\section{LITERATURE}

[1] Aleksić V. - Banka i moć, Stubovi kulture, Beograd, 2002

[2] Anderson R. - Transition banking, Oxford Clarendon, 1998

[3] Babić B. - Novi Bazelski sporazum o kapitalu, Spoljnotrgovinski savetnik, Poslovni biro, Beograd br. 4/2003.

[4] Baldvin R., Viploc Č. - Ekonomija evropskih integracija, Data Status, Beograd, 2010.

[5] Stošić Mihajlović, Lj. - Tržište, troškovi i cene, VŠPSS, Vranje

[6] Stošić-Mihajlović, Lj. [2015]. Conditionality economic policy and economic system. Journal of Process Management. New Technologies, 3(1), 7683.

[7] http://mondo.rs/tag10141/veroljubdugalic/1 